\title{
Analisis vegetasi dan struktur komunitas Mangrove Di Teluk Benoa, Bali
}

\author{
Dwi Budi Wiyanto ${ }^{\mathrm{a} *}$ and Elok Faiqoh ${ }^{\mathrm{a}}$ \\ ${ }^{a}$ Program Studi Ilmu Kelautan, Fakultas Kelautan dan Perikanan, Universitas Udayana, Bali, Indonesia \\ *Corresponding author. Tel.: +62-361-702-802 \\ E-mail address: wiyanto_marine@yahoo.com
}

Received: 3 January 2015; accepted: 5 September 2015; available online: 9 September 2015

\begin{abstract}
Mangrove forest is one of the natural resources having value and mean a lot both in terms of its physical, biological and socioeconomic. Due to the increasing needs of human's livelihood causing them to intervered in these ecosystems. It can be seen from the land's conversion of these mangroves into saltwater fishponds, human settlements, industrial areas and others. One of the mangrove area in Bali is Benoa Bay. This study aims is to determine the structure and vegetation and also the dominant mangrove species in the Benoa Bay mangrove forest in Bali. The method used in this study is a sample survey or a field survey method. At each observation station along the transect line, plots are made with a size of $10 \mathrm{~m} \mathrm{x} 10 \mathrm{~m}$ with 3 plots for each station. Then, on each observation plot any individuals mangrove species found are counted per each species. For the data analysis purposes, each trees, saplings and seedlings individual are noted its name type and the trunk circumference at chest level, while for vegetation strata seedling are noted its name type and the number of individuals of each species. For the mangrove vegetation were found that its consists of 11 true mangrove species and one species of mangrove follow which was Waru Sea (Thespesia popunema). At the I station, the tree level mangrove vegetation is dominated by Sonneratia alba (INP) counted to 130.61, as the seedlings level was dominated by Rhizophora mисronata (INP) of 246.11. At the II station, tree level mangrove vegetation is dominated by Rhizophora mucronata (INP) counted to 109.59 , while the seedling rate was dominated by Rhizophora stylosa (INP) of 91.60. At the III station, tree level mangrove vegetation is dominated by Rhizophora apiculata (INP) of 92.26, while the seedlings rate was dominated by Rhizophora apiculata (INP) of 82.89 . At the IV station, tree level mangrove vegetation is dominated by Sonneratia alba (INP) of 93.77, while the seedlings rate was dominated by Avicennia marina (INP) of 103.04. At station V, tree level mangrove vegetation is dominated by Bruguira gymnorrhyiza (INP) amounted to 115.31, while the seedlings rate was dominated by Rhizophora stylosa (INP) of 136.62.
\end{abstract}

Key Words: Vegetation Analysis, Community Structure, Mangrove, Benoa Bay

\begin{abstract}
Abstrak
Hutan mangrove merupakan salah satu sumber daya alam yang mempunyai nilai dan arti yang sangat penting baik dari segi fisik, biologi maupun sosial ekonomi. Akibat meningkatnya kebutuhan hidup sebagian manusia telah mengintervensi ekosistem tersebut. Hal ini dapat terlihat dari adanya alih fungsi lahan mangrove menjadi tambak, permukiman, areal industri dan sebagainya.Salah satu kawasan hutan mangrove di Bali adalah Teluk Benoa. Tujujan penelitian ini yaitu untuk mengetahui struktur dan vegetasi dan jenisjenis mangrove yang dominan di hutan mangrove Teluk Benoa-Bali. Metode yang digunakan dalam penelitian ini adalah sample survey method atau survey di lapangan. Pada setiap stasiun pengamatan sepanjang transek garis, dibuat petak (plot) dengan ukuran 10 meter x 10 meter sebanyak 3 plot untuk tiap stasiun. Selanjutnya pada setiap plot dilakukan pengamatan dan penghitungan jumlah individu mangrove per spesies yang ditemukan. Untuk keperluan analisis data, masing-masing individu pohon, anakan dan semai dicatat nama jenis dan keliling batang setinggi dada, sedangkan untuk vegetasi strata seedling dicatat nama jenis dan jumlah individu masing-masing jenis. Vegetasi mangrove yang ditemukan yaitu 11 spesies mangrove sejati dan 1 jenis mangrove ikutan yaitu Waru Laut (Thespesia popunema). Pada stasiun I, vegetasi mangrove tingkat pohon didominasi oleh Sonneratia alba (INP) sebesar 130.61, tingkat anakan didominasi oleh Rhizophora mucronata (INP) sebesar 246.11. Pada stasiun II, vegetasi mangrove tingkat pohon didominasi oleh Rhizophora mucronata (INP) sebesar 109.59, sedangkan tingkat anakan didominasi oleh Rhizophora stylosa (INP) sebesar 91.60. Pada stasiun III, vegetasi mangrove tingkat pohon didominasi oleh Rhizophora apiculata (INP) sebesar 92.26, sedangkan tingkat anakan didominasi oleh Rhizophora apiculata (INP) sebesar 82.89. Pada stasiun IV, vegetasi mangrove tingkat pohon didominasi oleh Sonneratia alba (INP) sebesar 93.77, sedangkan tingkat anakan didominasi oleh Avicennia marina (INP) sebesar 103.04. Pada stasiun V, vegetasi mangrove tingkat pohon didominasi oleh Bruguira gymnorrhyiza (INP) sebesar 115.31, sedangkan tingkat anakan didominasi oleh Rhizophora stylosa (INP) sebesar 136.62.
\end{abstract}

Kata Kunci: Analisis Vegetasi, Struktur Komunitas, Mangrove, Teluk Benoa 


\section{Pendahuluan}

Sebagai salah satu ekosistem pesisir, hutan mangrove merupakan ekosistem yang unik dan rawan. Ekosistem ini mempunyai fungsi ekologis dan ekonomis. Fungsi ekologis hutan mangrove antara lain : pelindung garis pantai, mencegah intrusi air laut, habitat, tempat mencari makan (feeding ground), tempat asuhan dan pembesaran (nursery ground), tempat pemijahan (spawning ground) bagi aneka biota perairan, serta sebagai pengatur iklim mikro. Sedangkan fungsi ekonominya antara lain : penghasil keperluan rumah tangga, penghasil keperluan industri, dan penghasil bibit.

Salah satu kawasan hutan mangrove di Bali adalah Teluk Benoa. Kawasan hutan mangrove mengalami tekanan yang sangat besar setelah adanya pembangunan tol, sehingga perlu untuk mengetahui vegetasi dan struktur komunitas hutan mangrove di Teluk Benoa-Bali.

Pembangunan wilayah pesisir di Provinsi Bali saat ini menghadapi permasalahan dasar, yaitu: (1) alih fungsi lahan mangrove menjadi area tambak, permukiman, area industri dan sebagainya; dan (2) perencanaan wilayah pesisir yang belum didasari oleh informasi tentang tingkat kondisi ekosistem wilayah pesisir yang akurat. Permasalahan tersebut disebabkan oleh beberapa hal, antara lain: (1) belum lengkapnya data atau informasi tentang sebaran dan kerapatan hutan mangrovedi wilayah pesisir untuk semua wilayah; dan (2) belum adanya data kondisi hutan mangrove di Provinsi Bali yang akurat. Hal ini penting untuk mengetahui daerah mana yang kondisi ekosistem mangrove tersebut masih bagus dan daerah mana yang mengalami kerusakan.

Adapun tujuan penelitian ini yaitu untuk mengetahui vegetasi, struktur komunitas dan jenis-jenis mangrove yang dominan di hutan mangrove Teluk Benoa-Bali. Sementara itu, dari penelitian ini diharapkan dapat memperoleh informasi tentang vegetasi dan struktur komunitas hutan mangrove di Provinsi Bali khususnya Teluk Benoa.

\section{Metode Penelitian}

\subsection{Metode}

Pengambilan sample dilakukan di 5 (lima) titik stasiun yang diambil secara acak dilokasi penelitian. Prosedur pengambilan data dan pengamatan vegetasi mangrove sesuai dengan metode yang telah dipublikasikan oleh Bengen (2001). Adapun prosedur lengkap dari pengamatan ekosistem hutan mangrove adalah sebagai berikut:

- Pada setiap stasiun pengamatan, tentukan petak-petak pengamatan/plot berukuran $10 \mathrm{~m} \times 10 \mathrm{~m}$ sebanyak minimal 3 plot. Untuk pohon ukuran transek nya adalah $10 \mathrm{~m}$ x $10 \mathrm{~m}$, untuk anakan ukuran transek nya adalah $5 \mathrm{~m} \times 5 \mathrm{~m}$, sedangakn untuk semai ukuran transeknya adalah $2 \mathrm{~m} \times 2 \mathrm{~m}$.

- Pada setiap plot yang ada determinasi setiap jenis tumbuhan mangrove yang ada, hitung jumlah individu setiap jenis dan ukur lingkar batang setiap pohon mangrove pada setinggi dada (sekitar 1.3 meter).

\subsection{Parameter utama}

Untuk mendapatkan informasi yang perlu diketahui tentang kondisi ekosistem mangrove digunakan metode analisa mencari Indeks Nilai Penting (INP). Indeks Nilai Penting ini memberikan suatu gambaran tentang pengaruh atau peranan suatu jenis tumbuhan mangrove dalam suatu area. Adapun analisa datanya sebagai berikut:

a. Kerapatan Jenis (Di) adalah jumlah tegakan jenis ke-I dalam suatu area

$$
D i=\frac{n i}{A}
$$

dimana Di adalah kerapatan jenis ke-i, ni adalah jumlah total tegakan dari suatu jenis dan A adalah luas total area pengambilan contoh (luas total petak contoh (plot) dalam $\mathrm{m}^{2}$.

b. Kerapatan Relatif Jenis (RDi) (\%) adalah perbandingan antara jumlah tegakan jenis ke-i dan jumlah tegakan seluruh jenis $(\Sigma \mathrm{n})$

$$
R D i=\left(\frac{n i}{\sum n}\right) \times 100
$$

c. Frekuensi Jenis (Fi) adalah peluang ditemukannya jenis ke-i, dalam petak contoh yang diamati

$$
F i=\frac{p i}{\sum p}
$$

dimana Fi adalah frekuensi jenis i, pi adalah jumlah petak contoh/plot dimana ditemukan jenis i, dan $\Sigma p$ adalah jumlah total petak contoh/ plot yang diamati.

d. Frekuensi Relatif Jenis (RFi) (\%) adalah perbandingan antara frekuensi jenis i (Fi) dan jumlah frekuensi untuk seluruh jenis $(\Sigma \mathrm{F})$

$$
R F i=\left(\frac{F i}{\sum F}\right) \times 100
$$

e. Penutupan Jenis (Ci) adalah luas penutupan jenis i dalam suatu unit area

$$
C i=\frac{\sum B A}{A}
$$

dimana $\mathrm{BA}=\Pi \mathrm{DBH}^{2} / 4\left(\right.$ dalam $\left.\mathrm{cm}^{2}\right), \pi=(3.1416)$ adalah suatu konstanta dan DBH adalah diameter pohon dari jenis i, A adalah luas total area pengambilan contoh (luas total petak contoh/plot). $\mathrm{DBH}=\mathrm{CBH} / \pi$, $\mathrm{CBH}$ adalah besarnya lingkaran pohon.

f. Penutupan Relatif Jenis (RCi) (\%) adalah perbandingan antara luas area penutupan jenis i $(\mathrm{Ci})$ dan luas total area penutupan untuk seluruh jenis $(\mathrm{\Sigma C})$

$$
R C i=\left(\frac{C i}{\sum C}\right) \times 100
$$

g. Jumlah nilai kerapatan relatif jenis (RDi), frekuensi relatif jenis (RFi) dan penutupan relatif jenis $(\mathrm{RCi})$ menunjukkan Indeks Nilai Penting (INP) untuk masing-masing jenis.

$$
I N P=R D i+R F i+R C i
$$

Nilai Penting suatu jenis berkisar antara 0-300. Indeks 
ini memberikan suatu gambaran mengenai pengaruh atau peranan suatu jenis tumbuhan mangrove dalam suatu komunitas.

h. Volume pohon $\left(\mathrm{m}^{3} / \mathrm{Ha}\right)=B a \times t \times 0,75$. Dimana $B a$ adalah luas bidang datar $\left(\mathrm{m}^{2} / \mathrm{Ha}\right)$ dan $t$ adalah tinggi pohon.

\section{Hasil dan Pembahasan}

\subsection{Kondisi ekosistem Mangrove}

Berdasarkan dari hasil pengamatan vegetasi mangrove dilokasi penelitian telah ditemukan 11 (sebelas) jenis vegetasi mangrove sejati dan 1 jenis mangrove ikutan yaitu Waru Laut (Thespesia popunema). Jenis vegetasi mangrove sejati yang ditemukan dalam pengamatan yaitu jenis Rhizopora mucronata, Rhizopora stylosa, Rhizophora apiculata, Avicenia marina, Avicenia officinalis, Sonneratia alba, Sonneratia caseolaris, Bruguiera gymnorrhyza, Bruguiera cylindrical, Xylocarpus granatum, Ceriop tagal.

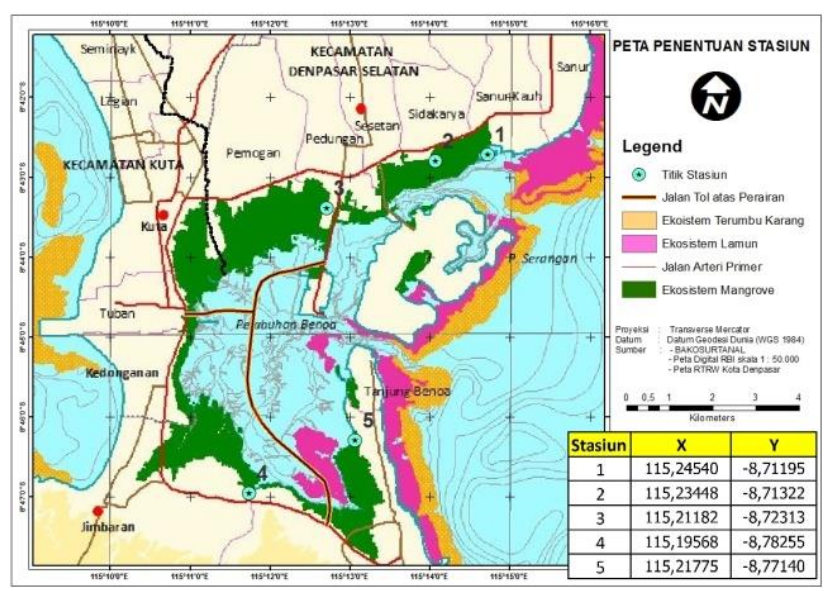

Gambar 1. Peta lokasi transek Mangrove di Teluk Benoa, Bali.

\subsection{Analisa jenis vegetasi Mangrove}

\subsubsection{Analisa jenis vegetasi Mangrove pada tingkat pohon}

Pada stasiun I ditemukan 3 (tiga) spesies mangrove yaitu Sonneratia alba, Rhizopora mucronata, Rhizopora stylosa. Hasil analisa tentang kerapatan relative jenis (RDi), frekuensi relative jenis (RFi) dan penutupan relative jenis $(\mathrm{RCi})$ diperoleh nilai penting suatu jenis mangrove yang terdapat di Teluk Benoa Bali, pada tingkat pohon di stasiun I, jenis vegetasi mangrove yang di temukan paling penting peranannya dilokasi pengamatan adalah Sonneratia alba dengan Indeks nilai penting (INP) yaitu sebesar 130.61, untuk Rhizopora mucronata dengan indeks nilai penting (INP) yaitu sebesar 92.83, sedangkan indeks nilai penting (INP) pada Rhizopora stylosa yaitu sebesar 76.56 (Gambar 2).

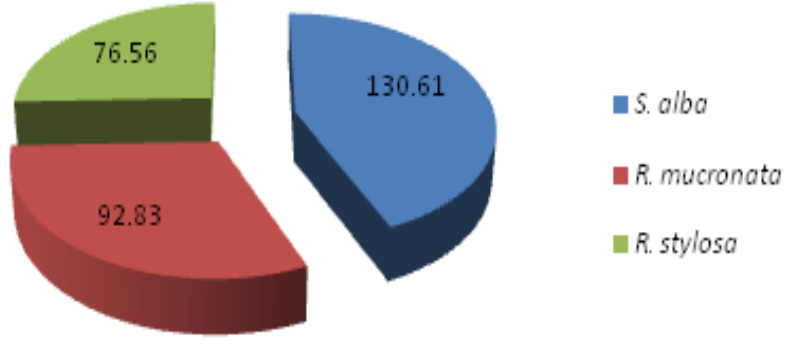

Gambar 2. INP Tingkat Pohon pada stasiun I.

Hasil pengamatan pada stasiun II, ditemukan 4 (empat) spesies mangrove yaitu : Rhizophora mucronata, Rhizophora stylosa, Rhizophoraapiculata, Xylocarpus granatum. Berdasarkan hasil analisa vegetasi mangrove pada stasiun II, kerapatan relative jenis (RDi), frekuensi relative jenis (RFi) dan penutupan relative jenis (RCi) diperoleh nilai penting suatu jenis mangrove pada tingkat pohon, jenis vegetasi mangrove yang di temukan paling penting peranannya dilokasi penelitian adalah Rhizophora mucronatadengan Indeks nilai penting (INP) yaitu sebesar 109.59, untuk Rhizophora stylosa dengan indeks nilai penting (INP) yaitu sebesar 68.97, Rhizophoraapiculata sebesar 61.59 dan Xylocarpus granatum sebesar 59.86 (Gambar 3).

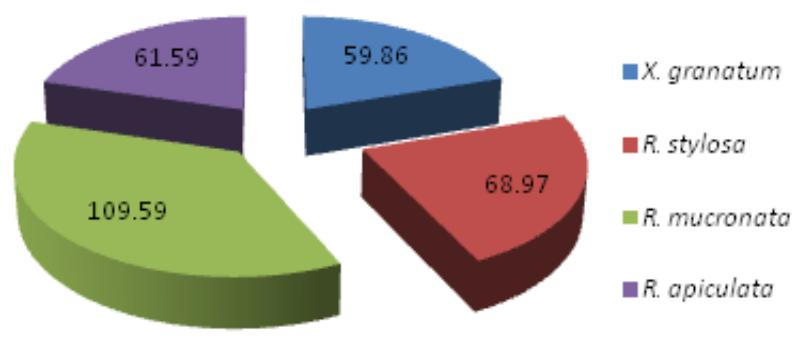

Gambar 3. INP Tingkat Pohon pada stasiun II

Berdasarkan hasil pengamatan vegetasi mangrove pada stasiun III, ditemukan 5 spesies mangrove yaitu Sonneratia alba, Xylocarpus granataumRhizophora mucronataSonneratia caseolaris,Rhizophora apiculata. Hasil analisa kerapatan relative jenis (RDi), frekuensi relative jenis (RFi) dan penutupan relative jenis (RCi) diperoleh nilai penting suatu jenis mangrove pada tingkat pohon, jenis vegetasi mangrove yang mempunyai nilai paling penting peranannya dilokasi penelitian adalah Rhizophoraapiculata dengan Indeks Nilai Penting (INP) yaitu sebesar 92.26, Sonneratia alba dengan Indeks Nilai Penting (INP) sebesar 69.02. Rhizophora mucronata dengan Indeks Nilai Penting (INP) yaitu sebesar 54.43, Xylocarpus granatum dengan Indeks Nilai Penting (INP) sebesar 48.43 dan Sonneratia caseolaris dengan Indeks Nilai penting sebesar 35.86 (Gambar 4). 

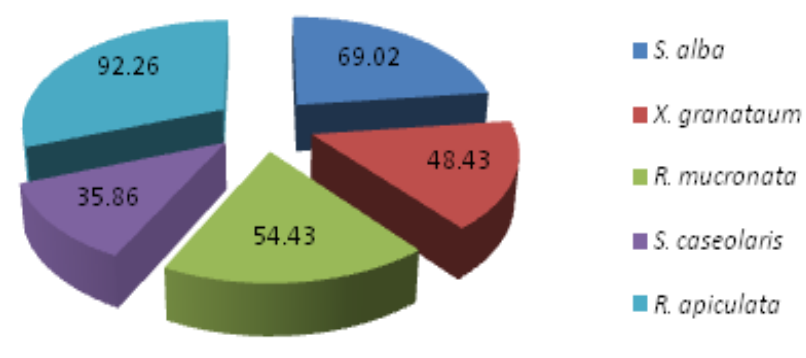

Gambar 4. INP Tingkat Pohon pada stasiun III

Hasil pengamatan dilokasi penelitian vegetasi mangrove pada stasiun IV, ditemukan 5 spesies mangrove yaitu Sonneratia alba, Bruguira gymnorrhyiza, Avicennia marina, Avicennia officinalis, Rhizophoraapiculata. Hasil analisa kerapatan relative jenis (RDi), frekuensi relative jenis (RFi) dan penutupan relative jenis $(\mathrm{RCi})$ diperoleh nilai penting suatu jenis mangrove pada tingkat pohon, jenis vegetasi mangrove yang mempunyai nilai paling penting peranannya dilokasi penelitian adalah Sonneratia alba dengan Indek Nilai Penting (INP) sebesar 93.77. Avicennia marina dengan Indeks Nilai Penting (INP) yaitu sebesar 87.57, Bruguira gymnorrhyiza dengan Indek Nilai Penting (INP) sebesar 76.88. Sonneratia alba dengan indeks nilai penting (INP) yaitu sebesar 20.93, Avicennia officinalis dengan Indek Nilai Penting (INP) sebesar 20.85 .

Hasil pengamatan dilokasi penelitian vegetasi mangrove pada stasiun $\mathrm{V}$, ditemukan 5 spesies mangrove yaitu Rhizophora stylosa, Bruguira gymnorrhyiza, Sonneratia alba, Bruguira cylindrical, Ceriop tagal (Gambar 5).

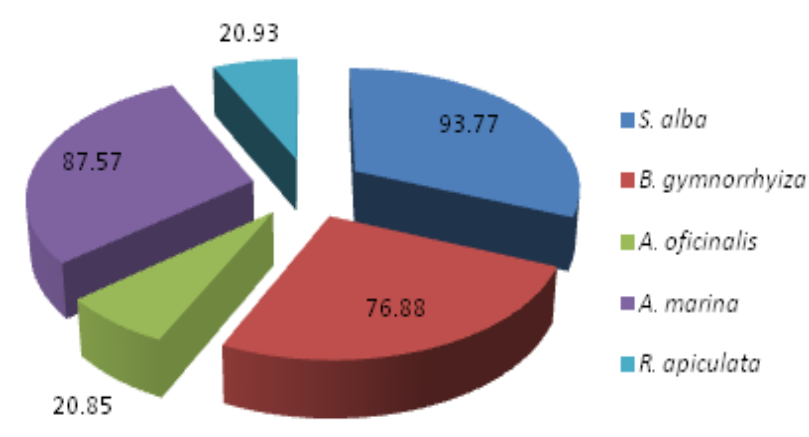

Gambar 5. INP Tingkat Pohon pada stasiun IV

Hasil analisa kerapatan relative jenis (RDi), frekuensi relative jenis (RFi) dan penutupan relative jenis (RCi) diperoleh nilai penting suatu jenis mangrove pada tingkat pohon, jenis vegetasi mangrove yang mempunyai nilai paling penting peranannya dilokasi penelitian adalah Bruguira gymnorrhyiza dengan Indek Nilai Penting (INP) sebesar 115.31. Rhizophora stylosadengan Indeks Nilai Penting (INP) yaitu sebesar 79.43, Bruguira cylindrical dengan Indek Nilai Penting (INP) sebesar 39.24. Sonneratia alba dengan indeks nilai penting (INP) yaitu sebesar 38.35, Ceriop tagal dengan Indek Nilai Penting (INP) sebesar 27.67 (Gambar 6).

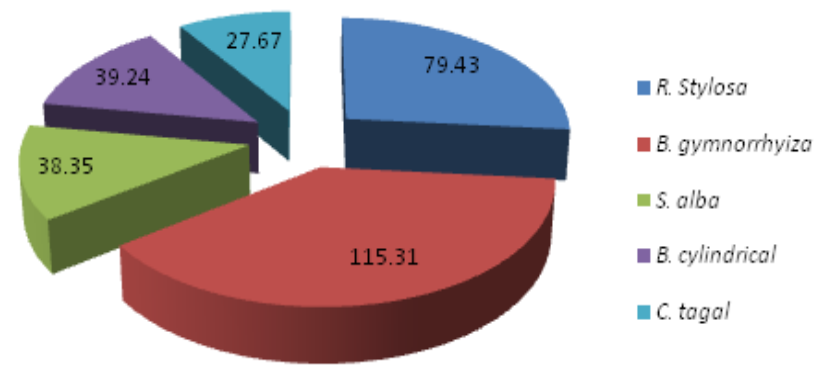

Gambar 6. INP Tingkat Pohon pada stasiun V

Sementara itu, nilai-nilai frekuensi relatif, kerapatan relatif, dominansi relatif dan nilai indek penting jenis tumbuhan mangrove pada tingkat pohon disajikan pada Tabel 1.

3.2.2. Analisa jenis vegetasi Mangrove pada tingkat anakan

Pada stasiun I ditemukan 2 (dua) spesies mangrove yaitu Rhizopora mucronata, Rhizopora stylosa. Hasil analisa tentang kerapatan relative jenis (RDi), frekuensi relative jenis (RFi) dan penutupan relative jenis (RCi) diperoleh nilai penting suatu jenis mangrove yang terdapat di Teluk Benoa Bali, pada tingkat anakan di stasiun I, jenis vegetasi mangrove yang di temukan paling penting peranannya dilokasi pengamatan adalah Rhizopora mucronata dengan indeks nilai penting (INP) yaitu sebesar 246.1, sedangkan indeks nilai penting (INP) pada Rhizopora stylosa yaitu sebesar 53.9 (Gambar 7).

Hasil pengamatan dilokasi penelitian vegetasi mangrove pada tingkat anakan di stasiun III, ditemukan 5 spesies mangrove yaitu Sonneratia alba, Xylocarpus granatum, Rhizophora mucronata, sonneratia caseolaris, Rhizophora apiculata.

Tabel 1

Frekuensi Relatif, Kerapatan Relatif, Dominansi Relatif dan Nilai Indek Penting Jenis Tumbuhan Mangrove Tingkat Pohon.

\begin{tabular}{|r|l|r|r|r|r|}
\hline Stasiun & Jenis Mangrove & RDi (\%) & RFi (\%) & RCI (\%) & \multicolumn{1}{c|}{ INP } \\
\hline & S. alba & 46.15 & 33.3 & 51.12 & 130.61 \\
\hline & R. mucronata & 30.77 & 33.3 & 28.73 & 92.83 \\
\hline & R. stylosa & 23.08 & 33.3 & 20.15 & 76.56 \\
\hline & & & & & \\
\hline II & X. granatum & 20 & 20 & 19.86 & 59.86 \\
\hline & R. stylosa & 20 & 20 & 28.97 & 68.97 \\
\hline & R. mucronata & 40 & 40 & 29.59 & 109.59 \\
\hline & R. apiculata & 20 & 20 & 21.59 & 61.59 \\
\hline & & & & & \\
\hline III & S. alba & 16.67 & 20 & 32.36 & 69.02 \\
\hline & X. granataum & 25.00 & 20 & 3.43 & 48.43 \\
\hline & R. mucronata & 16.67 & 20 & 17.77 & 54.43 \\
\hline & S. caseolaris & 8.33 & 20 & 7.52 & 35.86 \\
\hline & R. apiculata & 33.33 & 20 & 38.92 & 92.26 \\
\hline & & & & & \\
\hline IV & S. alba & 36.84 & 22.2 & 34.71 & 93.77 \\
\hline & B. gymnorrhyiza & 21.05 & 33.3 & 22.49 & 76.88 \\
\hline & A. oficinalis & 5.26 & 11.1 & 4.47 & 20.85 \\
\hline & A. marina & 31.58 & 22.2 & 33.77 & 87.57 \\
\hline & R. apiculata & 5.26 & 11.1 & 4.56 & 20.93 \\
\hline & & & & & \\
\hline V & R. Stylosa & 32.0 & 14.29 & 33.14 & 79.43 \\
\hline & B. gymnorrhyiza & 36.0 & 42.86 & 36.46 & 115.31 \\
\hline & S. alba & 12.0 & 14.29 & 12.07 & 38.35 \\
\hline & B. cylindrical & 12.0 & 14.29 & 12.95 & 39.24 \\
\hline & C. tagal & 8.0 & 14.29 & 5.38 & 27.67 \\
\hline & & & & & \\
\hline
\end{tabular}




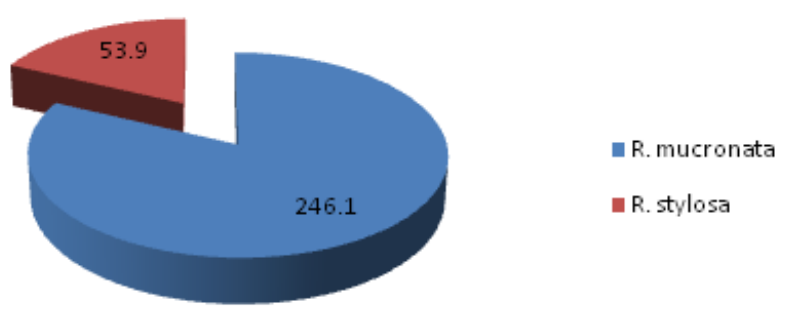

Gambar 7. INP Tingkat Anakan pada stasiun I

Hasil analisa kerapatan relative jenis (RDi), frekuensi relative jenis $(\mathrm{RFi})$ dan penutupan relative jenis (RCi) diperoleh nilai penting suatu jenis mangrove pada tingkat anakan di stasiun III, jenis vegetasi mangrove yang mempunyai nilai paling penting peranannya dilokasi penelitian adalah Rhizophora apiculata dengan Indek Nilai Penting (INP) sebesar 82.89. Rhizophora mucronatadengan Indeks Nilai Penting (INP) yaitu sebesar 80.51, Xylocarpus granatum dengan Indek Nilai Penting (INP) sebesar 55.64. Sonneratia alba dengan indeks nilai penting (INP) yaitu sebesar 53.32, Sonneratiacaseolaris dengan Indek Nilai Penting (INP) sebesar 27.63 (Gambar 8).

Hasil pengamatan dilokasi penelitian vegetasi mangrove pada tingkat anakan di stasiun II, ditemukan 4 (empat) spesies mangrove yaitu Rhizophora stylosa, Sonneratia alba, Rhizophora mucronata, Rhizophora apiculata. Hasil analisa kerapatan relative jenis (RDi), frekuensi relative jenis (RFi) dan penutupan relative jenis (RCi) diperoleh nilai penting suatu jenis mangrove pada tingkat anakan, jenis vegetasi mangrove yang mempunyai nilai paling penting peranannya dilokasi penelitian adalah Rhizophora stylosadengan Indek Nilai Penting (INP) sebesar 91.59. Rhizophora apiculata dengan Indeks Nilai Penting (INP) yaitu sebesar 81.544, Rhizophora mucronata dengan Indek Nilai Penting (INP) sebesar 63.44. Sonneratia alba dengan indeks nilai penting (INP) yaitu sebesar 63.40 (Gambar 9).
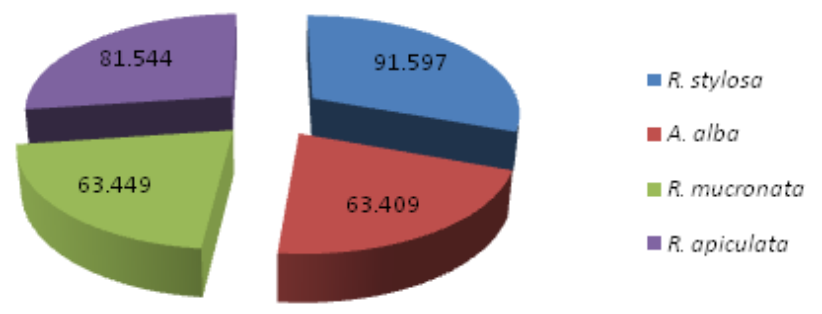

Gambar 8. INP Tingkat Anakan pada stasiun II
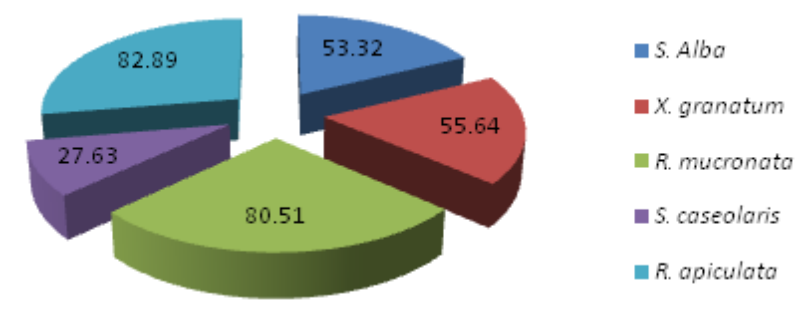

Gambar 9. INP Tingkat Anakan pada stasiun III
Berdasarkan hasil pengamatan dilokasi penelitian vegetasi mangrove pada tingkat anakan di stasiun IV, ditemukan 6 (enam) spesies mangrove yaitu Sonneratia alba, Bruguira gymnorrhyiza, Avicennia officinalis, Rhizophora apiculata, Avicennia marina, Rhizophora mucronata.

Hasil analisa menunjukkan kerapatan relative jenis (RDi), frekuensi relative jenis (RFi) dan penutupan relative jenis ( $\mathrm{RCi}$ ) diperoleh nilai penting suatu jenis mangrove pada tingkat anakan di stasiun IV, jenis vegetasi mangrove yang mempunyai nilai paling penting peranannya dilokasi penelitian adalah Avicennia marina dengan Indek Nilai Penting (INP) sebesar 103.04. Bruguira gymnorrhyiza dengan Indeks Nilai Penting (INP) yaitu sebesar 69.73, Sonneratia alba dengan Indek Nilai Penting (INP) sebesar 41.42. Rhizophora apiculata dengan indeks nilai penting (INP) yaitu sebesar 35.01, Avicennia officinalis dengan Indek Nilai Penting (INP) sebesar 32.92 dan Rhizophora mucronata dengan Indeks Nilai Penting (INP) sebesar 17.88 (Gambar 10).

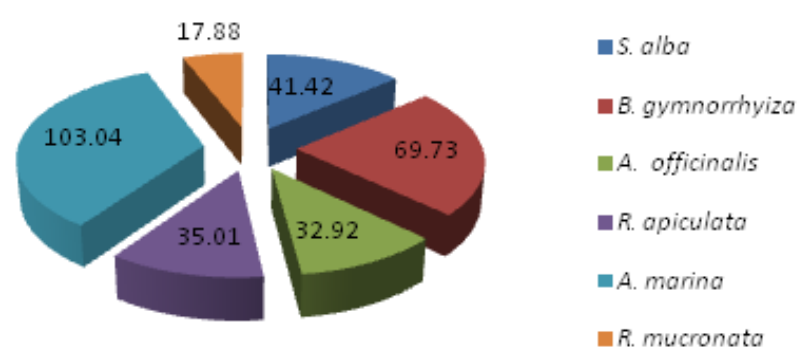

Gambar 10. INP Tingkat Anakan pada stasiun IV

Hasil pengamatan dilokasi penelitian vegetasi mangrove pada tingkat anakan di stasiun V, ditemukan 4 (empat) spesies mangrove yaitu Rhizophora stylosa, Bruguira gymnorrhyiza, Ceriop tagal, Sonneratia alba. Pada stasiun V, juga ditemukan jenis mangrove ikutan yaitu waru laut (Thespesia popunema).

Hasil analisa kerapatan relative jenis (RDi), frekuensi relative jenis (RFi) dan penutupan relative jenis (RCi) diperoleh nilai penting suatu jenis mangrove pada tingkat anakan di stasiun $\mathrm{V}$, jenis vegetasi mangrove yang mempunyai nilai paling penting peranannya dilokasi penelitian adalah Rhizophora stylosa dengan Indek Nilai Penting (INP) sebesar 136.62. Bruguira gymnorrhyiza dengan Indeks Nilai Penting (INP) yaitu sebesar 96.05, Sonneratia alba dengan Indek Nilai Penting (INP) sebesar 39.01. Ceriop tagal dengan indeks nilai penting (INP) yaitu sebesar 28.31 (Gambar 11).

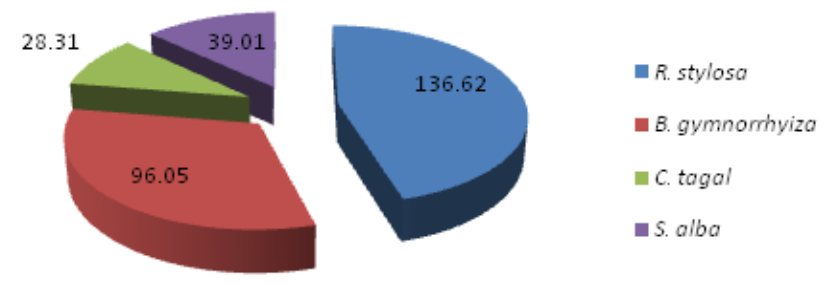

Gambar 11. INP Tingkat Anakan pada stasiun V

Sementara itu, nilai-nilai frekuensi relatif, kerapatan relatif, dominansi relatif dan nilai indek penting jenis 
tumbuhan mangrove pada tingkat anakan disajikan pada Tabel 2.

\section{Tabel 2}

Frekuensi Relatif, Kerapatan Relatif, Dominansi Relatif dan Nilai Indek Penting Jenis Tumbuhan Mangrove Tingkat Anakan.

\begin{tabular}{|c|c|c|c|c|c|}
\hline Stasiun & Jenis Mangrove & RDi (\%) & RFi (\%) & RCI (\%) & INP \\
\hline \multirow[t]{2}{*}{1} & R. mucronata & 87.10 & 75.00 & 84.01 & 246.11 \\
\hline & R. stylosa & 12.90 & 25.00 & 15.99 & 53.89 \\
\hline \multirow[t]{4}{*}{2} & R. stylosa & 30.61 & 33.33 & 27.65 & 91.60 \\
\hline & A. alba & 12.24 & 33.33 & 17.83 & 63.41 \\
\hline & R. mucronata & 24.49 & 16.67 & 22.29 & 63.45 \\
\hline & R. apiculata & 32.65 & 16.67 & 32.22 & 81.54 \\
\hline \multirow[t]{5}{*}{3} & S. Alba & 21.05 & 16.67 & 15.60 & 53.32 \\
\hline & X. granatum & 15.79 & 16.67 & 23.18 & 55.64 \\
\hline & R. mucronata & 21.05 & 33.33 & 26.13 & 80.51 \\
\hline & S. caseolaris & 5.26 & 16.67 & 5.70 & 27.63 \\
\hline & R. apiculata & 36.84 & 16.67 & 29.38 & 82.89 \\
\hline & & & & & \\
\hline \multirow[t]{6}{*}{4} & S. alba & 10.00 & 20.00 & 11.42 & 41.42 \\
\hline & B. gymnorrhyiza & 20.00 & 30.00 & 19.73 & 69.73 \\
\hline & A. officinalis & 10.00 & 10.00 & 12.92 & 32.92 \\
\hline & R. apiculata & 20.00 & 10.00 & 5.01 & 35.01 \\
\hline & A. marina & 36.67 & 20.00 & 46.37 & 103.04 \\
\hline & R. mucronata & 3.33 & 10.00 & 4.54 & 17.88 \\
\hline & & & & & \\
\hline \multirow[t]{4}{*}{5} & R. stylosa & 60.00 & 28.57 & 48.05 & 136.62 \\
\hline & B. gymnorrhyiza & 25.00 & 42.86 & 28.20 & 96.05 \\
\hline & C. tagal & 5.00 & 14.29 & 9.03 & 28.31 \\
\hline & S. alba & 10.00 & 14.29 & 14.72 & 39.01 \\
\hline
\end{tabular}

3.2.3. Kondisi kualitas perairan hutan Mangrove di Teluk Benoa

Pengukuran parameter perairan di lakukan tiap stasiun, Kualitas parameter perairan di lokasi Penelitian yang dilakukan di sekitar hutan mangrove antara lain salinitas 23-24\%o, DO 4.5-5.1, pH perairan 5.1-5.6, suhu 28-29 ${ }^{\circ} \mathrm{C}$, untuk tipe substrat di semua dominan berlumpur. Hasil pengukuran parameter perairan menunjukan masih mendukung untuk pertumbuhan mangrove.Tabel 5. Hasil pengukuran parameter lingkungan di kawasan hutan mangrove Teluk Benoa. Data kualitas perairan disekitar mangrove disajikan dalam Tabel 3.

Tabel 3

Hasil pengukuran parameter lingkungan di kawasan hutan mangrove Teluk Benoa.

\begin{tabular}{|l|l|l|l|l|l|}
\hline \multicolumn{1}{|c|}{ Kualitas air } & Stasiun I & Stasiun II & Stasiun III & Stasiun IV & Stasiun V \\
\hline Suhu $\left({ }^{0} \mathrm{C}\right)$ & 28 & 28 & 29 & 28 & 29 \\
\hline Salinitas $(0 / 00)$ & 24 & 23 & 23 & 25 & 24 \\
\hline DO & 4.8 & 4.9 & 5 & 4.9 & 5.1 \\
\hline pH & 5.1 & 5.4 & 5.2 & 5.5 & 5.6 \\
\hline Substrat & berlumpur & berlumpur & berlumpur & berlumpur & berlumpur \\
\hline
\end{tabular}

\section{Kesimpulan dan Saran}

\subsection{Kesimpulan}

Berdasarkan hasil penelitian ini dapat disimpulkan, vegetasi mangrove yang ditemukan yaitu 11 spesies mangrove sejati dan 1 jenis mangrove ikutan yaitu Waru Laut (Thespesia popunema). Jenis mangrove sejati yang ditemukan dalam pengamatan yaitu jenis Rhizopora mucronata, Rhizopora stylosa, Rhizophora apiculata, Avicenia marina, Avicenia officinalis, Sonneratia alba, Sonneratia caseolaris, Bruguiera gymnorrhyza, Bruguiera cylindrical, Xylocarpus granatum, Ceriop tagal. Hasil analisa vegetasi mangrove di Teluk Benoa yaitu:

1. Pada stasiun I, vegetasi mangrove pada tingkat pohon didominasi oleh Sonneratia alba dengan Indeks Nilai Penting (INP) sebesar 130.61, sedangkan pada tingkat anakan didominasi oleh Rhizophora mucronata dengan Indeks Nilai Penting (INP) sebesar 246.11.

2. Pada stasiun II, vegetasi mangrove pada tingkat pohon didominasi oleh Rhizophora mucronata dengan Indeks Nilai Penting (INP) sebesar 109.59, sedangkan pada tingkat anakan didominasi oleh Rhizophora stylosa dengan Indeks Nilai Penting (INP) sebesar 91.60.

3. Pada stasiun III, vegetasi mangrove pada tingkat pohon didominasi oleh Rhizophora apiculata dengan Indeks Nilai Penting (INP) sebesar 92.26, sedangkan pada tingkat anakan juga didominasi oleh Rhizophora apiculata dengan Indeks Nilai Penting (INP) sebesar 82.89 .

4. Pada stasiun IV, vegetasi mangrove pada tingkat pohon didominasi oleh Sonneratia alba dengan Indeks Nilai Penting (INP) sebesar 93.77, sedangkan pada tingkat anakan didominasi oleh Avicennia marina dengan Indeks Nilai Penting (INP) sebesar 103.04.

5. Pada stasiun $\mathrm{V}$, vegetasi mangrove pada tingkat pohon didominasi oleh Bruguira gymnorrhyiza dengan Indeks Nilai Penting (INP) sebesar 115.31, sedangkan pada tingkat anakan didominasi oleh Rhizophora stylosa dengan Indeks Nilai Penting (INP) sebesar 136.62.

\subsection{Saran}

Saran dari kegiatan penelitian tentang Analisis Vegetasi dan Struktur Komunitas Mangrove di Teluk Benoa-Bali ini, diharapkan dilakukan penelitian lanjutan, dengan memperbanyak stasiun, sehingga dapat diketahui vegetasi dan struktur mangrove yang lebih banyak.

\section{Daftar Pustaka}

Arikunto, S. 1993. Prosedur Penelitian Suatu Pendekatan Praktek. Rineka Cipta Jakarta.

Bengen, D.G. 2000. Sinopsis Ekosistem dan Sumberdaya Alam Pesisir. Pusat Kajian Sumberdaya Pesisir dan Lautan-Institut Pertanian Bogor. Bogor, Indonesia.

Bengen, D.G. 2001. Pedoman Teknis Pengenalan dan Pengelolaan Ekosistem Mangrove. Pusat Kajian Sumberdaya Pesisir dan Lautan-Institut Pertanian Bogor. Bogor, Indonesia.

Dahuri, M., J.Rais., S.P. Ginting., dan M.J. Sitepu. 1996. Pengelolaan Sumber Daya Wilayah Pesisir Secara Terpadu. PT. Pradnya Paramita. Jakarta, Indonesia.

Hadi, S. 1986. Metodology Research I. Yayasan Penerbit Fakultas Psikologi, UGM. Yogyakarta.

Idawaty. 1999. Evaluasi Kesesuaian Lahan dan Perencanaan Lansekap Hutan Mangrove Di Muara Sungai Cisadane, Kecamatan Teluk Naga, Jawa Barat. Tesis Magister. Program Pascasarjana Institut Pertanian Bogor. Bogor, Indonesia.

IUCN - The Word Conservation Union. 1993. Oil and Gas Exploration and Production in Mangrove Areas. IUCN. Gland, Switzerland. 
Kementerian Lingkungan Hidup (KLH). 2008. Status Lingkungan Hidup Indonesia 2007. Kementerian Negara Lingkungan Hidup RI.

Khazali, M. 1998. Panduan Teknis Penanaman Mangrove Bersama Masyarakat. Wetland International-Indonesia Programme. Bogor, Indonesia.

Nybakken, J.W. 1992. Biologi Laut Suatu Pendekatan Ekologis. Alih bahasa oleh M. Eidman., Koesoebiono., D.G. Bengen., M. Hutomo., S. Sukardjo. PT. Gramedia Pustaka Utama. Jakarta, Indonesia.

Santoso, N., H.W. Arifin. 1998. Rehabilitas Hutan Mangrove Pada Jalur Hijau Di Indonesia. Lembaga Pengkajian dan Pengembangan Mangrove (LPP Mangrove). Jakarta, Indonesia.
Santoso, N. 2000. Pola Pengawasan Ekosistem Mangrove. Makalah disampaikan pada Lokakarya Nasional Pengembangan Sistem Pengawasan Ekosistem Laut Tahun 2000. Jakarta, Indonesia.

Supriharyono. 2000. Pelestarian dan Pengelolaan Sumber Daya Alam di Wilayah Pesisir Tropis. PT Gramedia Pustaka Utama. Jakarta, Indonesia.

Widigdo, B. 2000. Diperlukan Pembakuan Kriteria Eko-Biologis Untuk Menentukan "Potensi Alami" Kawasan Pesisir Untuk Budidaya Udang. Dalam : Prosiding Pelatihan Untuk Pelatih Pengelolaan Wilayah Pesisir Terpadu. Pusat Kajian Sumberdaya Pesisir dan Lautan - Institut Pertanian Bogor dan Proyek Pesisir dan Coastal Resources Center-University of Rhode Island. Bogor, Indonesia.

(C) 2015 by the authors; licensee Udayana University, Indonesia. This article is an open access article distributed under the terms and conditions of the Creative Commons Attribution license (http://creativecommons.org/licenses/by/3.0/). 